other farms; (5) next to variety, season, and then soil, most affect the composition of swedes; the influence of manuring is not marked. The fourth conclusion is warranted by the facts which Mr. Collins brings forward, but this point is one on which further information is wanted, for it seems probable that the relative position of different varieties might change if the varieties were exposed to markedly different conditions.

A Bulletin reciently issued by the U.S. Department of Agriculture, entitled "The Mango in Porto Rico," discusses the prospects of mango cultivation on the island. Porto Rico grows mangoes in abundance; the climate is very favourable, and the trees are free from disease, but hitherto scedling trees only have been grown, and one is not surprised to read that the mangoes have met with but little favour in the American markets. The fame of the Bombay mango is due to the fruit of grafted trees, and it is rarely that trees raised from seed produce fruit worth eating. Seedling trees abound in every village, but firstrate trees are very uncommon. The short list given in Woodrow's "Gardening for India " shows how rare really good seedlings are. When the Americans import fine strains and take to growing grafted mango trees the industry is certain to make rapid progress. We gather from the' Bulletin that this subject is likely to engage the attention of the local experiment station. We hope it may, for if the matter is taken up with the energy characteristic of the American stations, there is every prospect of a great increase in the supply of the finest of tropical fruits.

\section{REPORT OF THE MALARIA EXPEDITION TO THE GAMBIA.}

THE Liverpool School of Tropical Medicine has just issued a most important and practical report upon the prevention of malaria in the tropics. ${ }^{1}$ Dr. Dutton, who conducted the expedition with conspicuous success, shows with striking clearness how a great deal of disease is due to the want of knowledge of the nature of malaria, and that during the dry season the residents are largely to blame for the appearance of the disease. It is one of the most hopeful reports ever issued by the school, and it shows that the governors and others in authority upon the coast are fully alive to the importance of stamping out malarial diseases. The report is an immense step forward in preventive medicine.

The object of the expedition was to investigate the conditions under which mosquitoes were propagated in the town of Bathurst and at the principal stations of the colony, and to suggest methods of destroying these insects. Malaria was found to be prevalent in the colony; 80 per cent. of the native children examined harboured malaria parasites in their blood. The liability to infection of the Europeans commences soon after the rains are established, lasting up to the end of November. The various breeding places of inosquitoes are described in detail in chapter iv, of the report, particular mention being made of the wells, canoes, boats, lighters, cutters on the foreshore, and of the grass-clogged trenches in many of the streets, which together supply Bathurst with the majority of its mosquitoes during the wet season and for part of the dry season. The number of mosquito breeding places present in compounds was found to vary with the social position of the occupier. They increased in extent and number in proportion to the wealth and position of the occupier.

An account of the examination of one of the large compounds illustrates to what extent mosquitoes are bred by the white man in the tropics on his own premises.

In one factory yard were found six barrels, and in the garden there were seventeen tubs and eight small wells, all breeding quantities of Culex, Stegomyia, and Anopheles mosquitoes. Besides these dry season breeding places, discarded domestic utensils were scattered about the yard and garden which, in the wet season, would have acted as breeding places. It is pointed out that during the dry season, from November to May, natural breeding places for 1 "Report of the Malaria Expedition to the Gambia, rgoz, of the Liverpuol School of "Tropical Medicine and Medical Parasitology." By J. F.

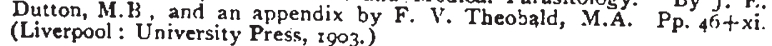
No. 1766 , voL. 68$]$ mosquitoes in Bathurst cease to exist, and from this period the people breed mosquitoes solely in their own compounds.

In chapter v., which deals with the prevention of malatia in Bathurst, a campaign against the mosquito is advocated the town is judged especially suitable for its success. Thus Bathurst is situated on a practically isolated piece of land surrounded on nearly all sides by a broad expanse of sea water. The amount of land to be dealt with is comparatively small, viz. about a square mile. The surface is fairly level, sandy, absorbing water readily. In this area the breeding places of mosquitoes are a known quantity, the artificial, or those made by man, being in excess of the natural. The rainfall is very small, and rain occurs only during four out of the twelve months of the year.

The probability of the introduction into Bathurst of yellow fever from Senegal is pointed out as another reason for attacking the mosquito. The expedition was informed by $\mathrm{His}$ Excellency the acting Governor, H. M. Brandford Ciriffith, of the intention on the part of the Colonial Government to enter upon a crusade against the mosquito, and on November is the preliminary removal of rubbish from houses and compounds began; a sanitary inspector was appointed, and received special instruction in the work. Lnder him worked a gang of labourers, and at the time of the departure of the expedition (January 10) 363 houses and compounds had been inspected. From these I3I cartload. of old tin pots and other rubbish were removed. On the return of His Excellency the Governor, Sir George C. Denton, the inspector and a sufficient staff of labourers were appointed permanently, and a grant of $200 l$. per annum was given for the special anti-mosquito work. Antimosquito regulations have been drawn up by the Colonial Government. These are given at the end of the report:

An apnendix, by Mr. F. V. Theobald, is attached to the report; in it are described the various species of mosquitoes collected by the expedition, many of which were new to sciense.

\section{ZONES IN THE CHALK.}

IN Nature for August 8,1901 , attention was directed to the second part of Dr. A. W. Rowe's researches on the zones of the White Chalk. We have now had the satisfaction of receiving the third part of this most interesting and important work, which deals with the Chalk of Devon (Proc. Geol. Assoc., vol. xviii. part i., I903).

Working the palacontology with such aids as can be gathered from the local stratigraphy and lithology, the author, assisted as before by Mr. C. D. Sherborn, has added extensively to our knowledge of the successive forms of life that are met with in the Chalk between Sidmouth and Lyme Regis. Whether or not the limits of the zones happen to coincide with definite stratigraphical limits, these latter afford useful data, and one marl band to which the author directs special attention, forms the plane of division between the zones of Terebratulina gracilis and Holaster planus. Such definite and continuous bands of rock (so far as they can be traced) must afford even more precise evidence of contemporaneity than the presence of this or that fossil. Even a tabular flintband has proved " an almost constant feature throughout the coast "--an interesting fact, and one that was not to bo expected. It is admitted that the name-fossils are not always confined to their zones. Holaster planus is found by Dr. Rowe throughout the zone of Terebratulina gracilis. But the guide-fossils, the general assemblages associated with the name-fossils, while they exhibit here, as elsewhere, local variations, tell the same story of the successive zones or stages of life, and indicate their approximate limits. Perhaps too much importance is given to the effort to fix a precise divisional plane between zones. When such divisions depend on the forms of life, and the succession of life is continuous though gradually varying, there can be no absolute planes of division, except through the absence or erosion of strata belonging to a particular perind of time.

The work before us is rich in its stores of interesting facts. The zone of Rhynchonella Cuvieri presents noteworthy features in the presence of Micraster cor-bovis and $M$ leskei, the zone of Terebratulina gracilis is "singulariy rich in fossils," while in the zones of Holaster planus and 